\title{
SOCIAL CAPITAL AS A CONSTITUTIVE ELEMENT OF PUBLIC SECURITY
}

\section{Kapitał społeczny elementem konstytutywnym bezpieczeństwa publicznego}

\begin{abstract}
When looking for new solutions to the old social problems, people pay attention to important issues for the good functioning of today's society, including interpersonal relations, trust, or standards. The term "social capital" has been used for several decades to describe and explain social and political as well as economic changes that took place as a result of the social and economic transformation. It also refers to activities including, among others, the creation of partnerships and democratic relations in local communities in which the social capital forms a basis of permanent networks of social involvement, trust, and mutuality. The purpose of this article is to present the benefits of the local community arising from social capital resources and their positive impact on public safety.
\end{abstract}

Keywords: social capital, trust, public security, principles of social life

Abstrakt: Szukając nowych rozwiazań dla starych problemów, zwraca się uwage na takie znaczace dla dobrego funkcjonowania wspótczesnego społeczeństwa kwestie jak sieci powiazań międzyludzkich, zaufanie czy normy. Pojęcie kapitału społecznego jest używane już od kilku dekad do opisu i wyjaśniania fenomenu zmian w sferze społeczno-politycznej i gospodarczej, zaistniatych w wyniku transformacji społeczno-ekonomicznej. Odnosi się ono również do sfery działań obejmujaccych m.in. budowanie partnerskich i demokratycznych relacji we wspólnotach lokalnych, w których kapitat społeczny stanowi podstawe trwałych sieci społecznego zaangażowania zaufania i wzajemności. Celem prezentowanego artykułu jest próba przedstawienia korzyści wynikających z posiadania przez wspólnotę lokalna zasobów kapitału społecznego, jak również wskazanie jego pozytywnego oddziaływania na bezpieczeństwo publiczne.

Słowa kluczowe: kapitat społeczny, zaufanie, bezpieczeństwo publiczne, zasady życia społecznego

1 Dr. habil. Monika Adamczyk, Assistant Professor, Katolicki Uniwersytet Lubelski Jana Pawła II w Lublinie, e-mail: monika.adamczyk@kul.pl, ORCID: 0000-0002-1331-6026 


\section{Introduction}

Since the mid-1990s, attention has been paid to the positive impact of social capital esources on social life. This extensive conceptual category, which includes at the same time trust, norms of reciprocity, cooperation and the ability to organise, is seen by analysts as a desirable and necessary component of social order. The literature distinguishes three main concepts of it. The first presents it as an "order of collective representations" in which social life is based on group conformism and regulated by traditional patterns. An order of this type is characteristic of rural collectivities and primitive societies. The second - monocentric order - assumes that social life is regulated by centrally made decisions of an organization that watches over their observance. Social life described by this concept is regulated by central decision-making centres and is characterized by a system of bureaucracy in which there is a hierarchy of positions. The third concept of social order is polycentric order, in which social equilibrium is achieved through individual interactions that respect the generally recognised rules of the game and norms of coexistence (Marinski 1993: 98). This analysis is based on the definition of socio-moral order, and in capturing this concept, it refers to the idea of the common good realized by the individual and the community (Marinski 1993: 99).

In this approach, social capital enables individuals and smaller social groups to take responsibility for their own actions in a changing society. This form of social participation is a very important element for the proper development of civil society as well as for economic development. Sustainable social development, based on trust and reciprocity, is one of the constitutive pillars of public security. Such development is characterised by the assumption that the needs of the present generation can be met without depriving future generations of that possibility through actions based on the principle of reciprocity and respect for the common good. This development refers to environmental, economic and social aspects (GUS 2011:4). What are the links between social capital, sustainable development and public security? To answer this question, it is first necessary to make some conceptual clarifications. 


\section{The concept of social capital}

Searching for solutions to the many problems affecting contemporary society, not only in Poland, scholars representing various fields of science - including economists, sociologists and political scientists - pay attention to such issues as networks of interpersonal relations, trust and norms inducing cooperation. The concept of social capital has for several decades been used to describe and explain new phenomena in the socio-political and economic sphere. The term has become so capacious and ambiguous that new generations of authors are still pondering over its meaning and functions at the micro-, meso- and macro-social levels. So what is social capital?

At the micro-social level, social capital is presented as a type of resource available to an individual. At the meso-social level, it is a group resource (e.g. local communities or workplaces), while at the macro-social level it is determined by social development factors (Przymeński 2005: 22). The concept of social capital is conceptualised in various ways. In this article, it will be developed with reference to the theories of Robert Putnam, Francis Fukuyama and James Coleman, who see social capital as the stock of human knowledge and skills, as well as such - important for the development of the community - features as trust, norms binding in a given community or connections, which may influence the increase of the community's efficiency (Lewenstein 2006: 165).

Trust, norms and connections facilitate coordination, with horizontal rather than vertical links in civic engagement being essential. Networks of connections that are informal, horizontal and personal in nature benefit the economy. On an individual scale, such strong community ties may bring economic benefits, because in a particular community, between people who know each other, it may be easier to establish understanding and trust, which from an economic point of view may positively influence transaction costs (Stańczak 2000: 485). However, it is pointed out that not every communal bond generates economic benefits. If loyalty to "one's own", e.g. one's family, prevails over rational action, then group solidarity is not conducive to placing trust in "strangers" - members of other social groups or other societies (Putnam 1995: 269). Thus, the ability of social capital to stimulate in a community the willingness to sacrifice the particular good - the interest of one's own group - for the good of society as a whole is always linked to a specific class society, which, as P. Bourdieu 
emphasized, always puts the interest of some classes or groups above the interest of others (Bourdieu 2005: 129-201). Consequently, the action of all for the creation of social capital as a common good can take place, according to J. Coleman, only under specific circumstances. "Only under conditions of the most far-reaching consensus does action flow spontaneously from the individual goals of those who are acting. In every other situation, spontaneous action does not occur, because at least one person wishes something different" (Coleman 1992: 345).

From the point of view of the conducted analyses, an extremely interesting concept concerning social capital is the one proposed by J. Coleman. In his analyses, he combines two different theories: a sociological theory of social relations in which the individual is a product of socialization, and the other - represented by neo-liberal economists who see the individual as determined by self-interest and the pursuit of maximum benefits. J. Coleman aims at combining both of these perspectives - sociological and economic - and the concept of social capital is his tool. This sociologist is primarily concerned with the interrelationship between the development of human and social capital. It is precisely this assumption that is crucial for the analysis of the relationship between social capital and public security. According to J. Coleman, social structure is formed as a result of activities performed by rational actors who are the product of the socialization process, and the actions taken by these actors are regulated by norms, rules and obligations. It also includes formal organizations, dispersed communities and loose networks. This structure becomes social capital when some actor uses it to achieve his own goal (Coleman 1988: 95-109).

J. Coleman defines social capital by the functions it performs, i.e. by phenomena that have one common denominator - they all have the characteristics of the structure and facilitate certain actions of actors within that structure. Thus, social capital is the ability of people to cooperate with one another, both within a group and within an organization, in order to pursue common interests. Social capital facilitates joint action, fills the social space between people, and is derived from interactions through which ties and networks of social bonds are based on a healthy foundation of cooperation. As with other forms of capital, social capital also serves to enhance performance as well as to develop the organization (Coleman 1990: 308-310).

As J. Coleman points out, the need and ability of people to join together with the intention of achieving some common goals applies not only to economic goals but also to other aspects of social life. "Like other forms of 
capital, social capital is productive - it makes possible certain goals that would be impossible to achieve in its absence (...)" (Coleman 1988: 95).

\section{Public safety and the community}

In attempting to demonstrate the mutual relations between social capital and public safety, reference should be made, firstly, to the concept of public safety and, secondly, to the basic principles of social life, which are closely related to the concept of social capital. Public security is a constitutional value, for the protection of which it is possible to limit the exercise of constitutional freedoms and rights by a citizen. However, each of the six categories of detailed interests enumerated in Article 31 Paragraph 3 of the Constitution of the Republic of Poland (public security and order, environmental protection, health, property and public morality) should be defined on the basis of the axiology of the foundations of the Constitution, with reference to, inter alia, the principle of human dignity and the prohibition of discrimination. Security of a democratic state in the context of the above-quoted article of the Fundamental Law is treated as a value included in the public interest, i.e. the general determinant of the limits of freedom and rights of the individual, where the public interest should not be identified with the state interest, nor should it be contrasted with the duties of the individual. The notion of "public security" marks the horizon of the most important tasks of the state and its most important function, however, so far it has not been precisely defined in legal regulations. In the literature, this issue is very often presented in a fragmentary way. It should also be emphasized that public security is not an abstract concept of administrative law science (Filaber 2016). Maintaining public safety is among the oldest public tasks and is closely related to the basic function of public authority. Due to centuries of tradition, this function of power has long been known, rooted in social consciousness and commonly understood.

In the context of this analysis, it is worth focusing on the notion of the local community. In the literature on the subject, there are two main approaches to this term. In the first one, the notion of community is reduced mainly to emotional bonds, collective identity, the social agreement based on direct contact and personal acquaintance. A community understood in 
this way is a community whose essence is expressed in "experiencing and sharing the same symbols and values that are the source of the group's cultural identity; objective dependencies and relations that are formed between people; respecting the principles of understanding and cooperation" (Starosta 2002: 98). The second orientation takes into account the following features of the community: a common territory, a common social interest that unites the inhabitants of the territory and that results from the use of this territory, interactions between people living in the territory and local sentiment (Starosta 2002: 98).

In this article, the local community will, to some extent, combine both approaches, which means that it will be understood as a community not only inhabiting a common territory but also based on a permanent system of social ties and interactions. The characteristic feature of the local community in such an approach is the strong sense of individuals' belonging to the group and their identification with the group (Olechnicki, Załęcki 1997: 201). Assuming that a strong sense of belonging and strong identification of the individual with the group will be associated with consent to take necessary actions to guarantee undisturbed and citizen-compliant functioning of the state, local government and social institutions and public facilities, as well as safety of life, health and property of the population as a result of compliance with the legal order accepted by the citizens, one should assume the existence of a strong norm of reciprocity and a high level of generalised trust. It is trust and norms of reciprocity, loyalty, honesty, reliability and responsibility that increase the ability of individuals to cooperate and the propensity to form lasting ties in society. They thus assume the role of constitutive elements of public security (Fukuyama 1997: 38). The relationship between public safety and the resources of social capital is thus due to the ability of the latter to spread trust within a society or a part of it - trust in institutions, people, authorities. F. Fukuyama emphasises very clearly that the impact of generalised trust sustains and multiplies cooperation between strangers, and the effect of this process is the creation of inclusive social capital including strangers into the circle of the cooperating community (Fukuyama 2003: 157). In the case of Polish society, the level of generalised trust is low. The Public Opinion Research Center, which has been monitoring this issue for 18 years, clearly emphasises in its reports that people who believe that most people can be trusted belong to the minority. In the 2020 report. "Social trust" such a belief was declared by less than one in four respondents (22\%), and the vast majority of respondents were of the opinion that one should be very careful 
in relations with others (76\%) (CBOS 2020). Importantly, from the point of view of the development of inclusive social capital resources, opinions on this subject have practically not changed over the past eight years. The view that most people can be trusted is expressed somewhat less frequently than in 2008 (26\% of all respondents) and 2010 (also 26\%) (CBOS 2008; CBOS 2010), and somewhat more frequently than in 2002 and 2006 (19\% and 19\% respectively) (CBOS 2002; CBOS 2006).

When analysing the relationship between social capital resources and public security, one should refer to three basic rules of social life. The first of these is the principle of the common good, which obliges members of both smaller and larger communities to take joint action to realize the common good (Coleman 1988: 95). Social capital is thus a factor facilitating joint action.

Another principle of social life that corresponds with the notions of social capital and public safety is the principle of solidarity. It obliges individuals and communities to take into account in social life both the common good and the good of the individual (Piwowarski 1993: 131). Social capital, in turn, means mutual obligations and expectations, common norms and sanctions, as well as the flow of information, i.e., everything that is necessary for people to cooperate in order to achieve some common good (Balcerzak-Paradowska 2004: 95-99). In building social capital, norms and values, as well as the ability of members of a community to sacrifice one's good for the social good are of particular importance (Coleman 1990: 306-313). A detailed description of action based on social capital resources is presented by J. Coleman, for whom obligations are capital resulting from mutual support. When one person helps another, the latter feels obliged to help the former. Information is nothing but capital that arises from contact with other people, resulting in the flow of knowledge from one person to another who does not have it, all within the framework of social relations maintained by the individual. Norms, in turn, are the part of social capital that is contained in the community itself and allows the community to act effectively (Coleman 1990: 306-313). The norm itself is defined by J. Coleman as a rule of behaviour approved by a given community, which defines what kind of behaviour in a given situation is socially accepted and what is not (e.g. norms that encourage learning, scouting or discourage contact with subcultures or undertaking criminal activities). (Coleman 1990: 308-310). The common good, a strong, internally integrated group do not emerge quickly. Generating social capital, just like creating any other form of capital, requires - according to Coleman - time and continuity of 
actions. The above-mentioned principles do not exhaust the list of all indications that operate in the sphere of social life, but only those that directly correspond to the notion of social capital and public safety.

Showing the relationship between social capital, public safety and the rules of social life, it is important to emphasize the existence of a feedback loop between these three elements. Observance of the rules of social life, strong integration into the group based on the key elements of social capital, such as trust, the norm of reciprocity, provide the basis for maintaining public safety in its various dimensions.

\section{Key areas of gains from community ownership of social capital resources}

The literature indicates that regardless of how the concept of social capital is conceptualised - as a private good (P. Bourdieu) or a public good (J. Coleman, R. Putnam, F. Fukuyama) - it is possible to speak of three key areas of gains that this resource brings, both in the economic, political and social sphere, where social capital directly contributes to solving social problems. Speaking of "purely economic" benefits resulting from the possession of social capital by a group, an increase in the productivity of other capitals - physical, material - or savings in transaction costs are given as examples. In a community characterised by a high level of generalised trust, i.e., trust in others, i.e., "strangers" and trust in institutions, there is a significantly higher propensity to undertake cooperation and mutual co-operation. Trust is an essential component of social capital. "Cooperation is often necessary - between the legislature and the executive, between workers and managers, between political parties, between government and private groups, between small groups (...) Trust drives cooperation. The greater the level of trust within a community, the greater the likelihood of cooperation. In turn, cooperation magnifies trust. This steady accumulation of social capital is an essential element of positive feedback" (Putnam 1995: 264-265). Such a state of affairs, when accompanied by other relevant factors, e.g. the economic prosperity of the country, may result in the establishment of new enterprises or the expansion of the scale of transactions to other entities. Thus, this process increases the productivity of other forms of capital without generating higher costs. This means a broadly understood 
reduction of transaction costs, i.e. the costs of acquiring information and protecting against the risk resulting from the unreliability of a partner in "business". In a community with a high level of social capital, a dense network of contacts is created between entities, which allows for social control and the application of social sanctions against an unreliable business entity. Often, such a sanction is much more effective than one resulting from the law, as social norms, which are the source of internal, informal social control, obviate the need to introduce more formal and institutional sanctions into the network (Putnam 1995: 258-264). Social norms are unwritten but universally understood laws that determine what forms of behaviour are desirable, valued and approved in a given social context. Community, on the other hand, as a mixture of trust, networks, norms and reciprocity, creates a strong community in which there is not only a commonly shared ownership of resources but also a community of values and norms.

In the literature, the gains from social capital in the political sphere are presented as a very complex issue. Presenting them in a rather general way, two main areas of their occurrence can be pointed out. The first of them, extremely important from the point of view of the issue under consideration, is the ability of social groups to organize themselves outside of state institutions. The second area is the ability to influence state and local government institutions (Theiss 2006: 121). It should be clearly emphasised that both these levels translate into the democratisation of social life, and thus co-creation of civil society closely connected with the maintenance of public safety. The ability of social groups to self-organise outside of local and government institutions results from the values they share and the community of purpose for which these organisations are created. The willingness to organize also stems from the fact that people who form organizations participate in various types of networks. Participation in networks and the existence of more or less dense, interwoven connections between individuals and groups is the key to the creation of social capital. Individuals interact with each other by forming voluntary relationships. Social capital cannot be built through actions taken solely for one's own benefit. This property makes it dependent on the ability of individuals to act collectively and on their ability to establish and maintain new links, contacts and ultimately networks.

Influencing state and local government institutions is subject to the rule that social capital enhances proactivity. The development of social capital requires people to be willing and active in their participation in community 
activities. Proactive people are the citizens of organizations who interact with each other in formal and informal structures, thus creating a social environment that can increase the effectiveness of state institutions. Modern concepts of local development promote an approach according to which one of the basic resources for local development are institutionalised social networks created around local organisations (especially NGOs), social groups and inhabitants (Lewenstein 2006: 167). This is because they increase the capacity for collective communication and self-organisation of local communities, e.g. in order to formulate demands to the authorities, create pressure and control groups, and support state services in carrying out tasks in more informal spheres, such as hospice care. These claims are in line with Putnam's views that horizontal institutionalized social networks have much better consequences for civic cooperation. Putnam defines social capital as a set of informal values and ethical norms shared by members of a particular group that enable them to cooperate effectively.

\section{Conclusions}

The benefits of a community's social capital go far beyond the economic and political sphere shaping a well-functioning civil society (Popławski 2008: 319). Social capital influences the quality of life of local communities and individuals, contributing to solving social problems and individual life crises. How does this happen? On the basis of certain behavioural patterns, mutual trust, the norm of reciprocity influencing the propensity for cooperation and the sphere of work and employment, a network of contacts available to the individual is created, especially those weak in terms of frequency and the basis of ties. Social capital means the action of some people for the benefit of others, even at the expense of their own interest, assuming, however, the expectation that this action will be reciprocated in the future.

The presence of social capital is conducive to people coming out of their social isolation and taking effective actions that motivate institutions to solve local community problems more efficiently. Public safety as understood in this analysis may be maintained thanks to the culture of trust and cooperation that are the constitutive elements of social capital. It is these elements that foster the upbringing of citizens who are more aware of their 
social role, thanks to which public institutions responsible for the economic development of regions and countries function more efficiently (Field 2003: 32). The main function of social capital is to reduce the level of uncertainty in social life, as it opens the possibility of increasing the economic activity of individual actors and reducing some of the transaction costs (March 2009: 110). Thus, regardless of whether we treat social capital as a feature of small social groups or, on the contrary, as an attribute of larger social systems, trust spread on various levels of life guarantees cooperation that can bring benefits and builds collective welfare, a sense of security and responsibility for one's own fate. The transformations that are taking place in contemporary societies prove the necessity to study the mechanisms of social capital formation and to raise awareness of the significant benefits of possessing it.

\section{Bibliographical note}

The article uses the materials contained in the author's earlier works:

Adamczyk, M. (2017), Zasoby kapitału społecznego a wzrost bezpieczeństwa publicznego [Social capital resources and the growth of public security], [in:] U. Soler, M.L. Górka (eds.), Globalne i lokalne wyzwania w obszarze wspótczesnej polityki bezpieczeństwa [Global and local challenges in the area of contemporary security policy], (Poznań: Media-Expo Poznań): 197-11.

Adamczyk, M. (2013), Wprowadzenie do teorii kapitatu społecznego [Introduction to the theory of social capital], (Lublin: Wydawnictwo KUL).

Adamczyk, M. (2012), Kapitat społeczny szansa na budowanie partnerskich relacji we wspólnotach lokalnych [Social capital as an opportunity to build partner relations in local communities], [in:] T. Zbyrda, B. Krempa (eds.), Pomoc jako zachowanie prospołeczne, [Help as prosocial behaviour], (Lublin: Wydawnictwo KUL): 489-500.

Adamczyk, M. (2011), Kapitat społeczny a sieci relacji we wspólnotach lokalnych [Social capital and networks of relations in local communities], [in:] S. Partycki (ed.), Społeczeństwo sieci. Gospodarka sieciowa w Europie Środkowej i Wschodniej [Network society. Network Economy in Central and Eastern Europe], vol. 1, (Lublin: Wydawnictwo KUL): 316-326. 


\section{References}

Bourdieu, P. (2005), Dystynkcja. Spoteczna krytyka władzy sadzenia [Distinction. A social critique of the power of judging], (Warszawa: Wydawnictwo Naukowe SCHOLAR).

Balcerzak-Paradowska, B. (2004), Rodzina i polityka rodzinna na przełomie wieków. Przemiany, zagrożenia, potrzeba dziatan [Family and family policy at the turn of the century. Changes, threats, the need for action], (Warszawa: Wydawnictwo Instytutu Pracy i Spraw Socjalnych).

CBOS (2002), Jacy jesteśmy? Zaufanie Polaków do ludzi i instytucji publicznych oraz gotowość do wspótpracy [What are we like? Trust of Poles in people and public institutions and willingness to cooperate], Research Communication BS/40/2002, https:// www.cbos.pl/SPISKOM.POL/2002/K_040_02.PDF (7.09.2021).

CBOS (2006), Zaufanie w sferze prywatnej i publicznej a spoteczeństwo obywatelskie [Trust in the private and public sphere and civil society], Research Communication BS/24/2006, https://www.cbos.pl/SPISKOM.POL/2006/K_024_06.PDF (7.09.2021).

CBOS (2008), Zaufanie społeczne w latach 2002-2008 [Social trust in 2002-2008], Research communication BS/30/2008, https://www.cbos.pl/SPISKOM.POL/ 2008/K_030_08.PDF (7.09.2021).

CBOS (2010), Zaufanie społeczne [Social trust], Research communication BS/29/2010, https://www.cbos.pl/SPISKOM.POL/2010/K_029_10.PDF (7.09.2021).

CBOS (2020), Zaufanie społeczne [Social trust], Research communication No. 43, https://www.cbos.pl/SPISKOM.POL/2020/K_043_20.PDF (7.09.2021).

Coleman, J. (1988), Social Capital in the Creation of Human Capital, "American Journal of Sociology", 94: S95-S122.

Coleman, J. (1990), Foundations of Social Theory, (Cambridge: Harvard University Press).

Coleman, J. (1992), Podstawy teorii decyzji zbiorowych [Foundations of collective decision theory], [in:] M. Kempny, J. Szmatka (eds.), Wspótczesne teorie wymiany spotecznej [Contemporary theories of social exchange], (Warszawa: Wydawnictwo Naukowe PWN): 346-362.

Field, J. (2003) Social Capital, (London-New York: Routledge).

Filaber, J. (2009), Pojęcie bezpieczeństwa publicznego w prawie administracyjnym (wybrane uwagi) [The concept of public safety in administrative law (selected remarks)], "Wrocławskie Studia Erazmiańskie", 3, http://www.repozytorium.uni.wroc. pl/Content/34474/016.pdf (12.02.2021).

Fukuyama, F. (2003), Kapitat spoteczny [Social capital], [in:] L.E. Harrison, S.P. Huntington (eds.), Kultura ma znaczenie. Jak wartości wptywają na rozwój społeczeństw [Culture matters. How values affect the development of societies], (Poznań: Wydawnictwo Zysk i S-ka): 169-187. 
Fukuyama, F. (1997), Zaufanie. Kapitał społeczny a droga do dobrobytu [Trust. Social capital and the road to prosperity], (Warszawa-Wrocław: Wydawnictwo Naukowe PWN).

CSO (2011), Wskaźniki zrównoważonego rozwoju Polski [Indicators of sustainable development of Poland], (Katowice), http://stat.gov.pl/obszary-tematyczne/inne-opracowania/inne-opracowania-zbiorcze/wskazniki-zrownowazonego-rozwoju-polski,5,1.html (1.03.2021).

Kitler, W. (2011), Bezpieczeństwo narodowe RP. Podstawowe kategorie, uwarunkowania, system [National Security of Poland. Basic categories, determinants, system], (Warszawa: Wydawnictwo Akademii Sztuki Wojennej).

Constitution of the Republic of Poland of 2 April 1997, Dz.U. 1997 No. 78, item 483 with subsequent amendments.

Lewenstein, B. (2006), Społeczeństwo rodzin czy obywateli - kapitał społeczny Polaków okresu transformacji [Society of families or citizens - social capital of transformed Poles], “Societas/Communitas", No. 1: 163-196.

Mariański, J. (1993), Religia i Kościół w społeczeństwie pluralistycznym. Polska lat dziewięćdziesiatych [Religion and the Church in a Pluralistic Society. Poland in the nineties], (Lublin: Redakcja Wydawnictw KUL).

Mariański, J. (2007), Postmodern society and its moral dilemmas [Społeczeństwo ponowoczesne i jego dylematy moralne], [in:] S. Partycki (ed.), Nowoczesność, ponowoczesność. Społeczeństwo obywatelskie w Europie Środkowej i Wschodniej, [Modernity, postmodernity. Civil society in Central and Eastern Europe], t. 1, (Lublin: Wydawnictwo KUL): 24-35.

Marzec, M. (2009), Zaufanie do podmiotów sfery publicznej w budowaniu kapitatu społecznego wspólnoty lokalnej [Trust in entities of the public sphere in building social capital of the local community], "Organizacja i Kierowanie (Organization and Management)", 3: 109-123.

Nowak, E. (2007), Zarządzanie kryzysowe w sytuacjach zagrożeń niemilitarnych, [Crisis management in non-military threats] (Warszawa: Academy of National Defence).

Olechnicki, K., P. Załęcki (1997), Słownik socjologiczny, [Dictionary of Sociology], (Toruń: Graffiti BC).

Piwowarski, W. (1993), Słownik Katolickiej Nauki Społecznej [Dictionary of Catholic Social Teaching], (Warszawa: PAX-Palabra).

Popławski, T. (2008), Kapitał społeczno-kulturowy wsi podlaskiej [Socio-cultural capital of Podlasie village], [in:] J. Kurczewska (ed.), Oblicza lokalności. Ku nowym formom życia lokalnego [Faces of the local. Towards new forms of local life], (Warszawa: Wydawnictwo IFiS PAN): 319-331.

Przymeński, A. (2005), Kapitał społeczny a społeczeństwo [Social capital and society], [in:] H. Januszek (ed.), Kapitat społeczny we wspólnotach [Social capital in communities], (Poznań: Wydawnictwo Akademii Ekonomicznej w Poznaniu): 22-30. 
Putnam, R. (1995), Demokracja w dziataniu. Tradycje obywatelskie we wspótczesnych Wtoszech [Democracy in action. Civic traditions in contemporary Italy], (Kraków: Znak).

Stańczak, Z.J. (2000), Kapitał społeczny a społeczna gospodarka rynkowa (Social Capital and Social Market Economy), [in:] S. Partycki (ed.), Społeczna gospodarka rynkowa w Polsce. Model a rzeczywistość. III Międzynarodowa Konferencja Socjologiczna, Natęczów 15-17 czerwca 2000 [Social market economy in Poland. Model and reality. III International Sociological Conference, Nałęczów, June 15-17, 2000], (Lublin: Wydawnictwo UMCS): 483-491.

Starosta, P. (2002), Spoteczność lokalna, [Local society], [in:] K.W. Friske (ed.), Encyklopedia socjologii, [Encyclopedia of Sociology] t. 4, (Warszawa: Oficyna Naukowa): 97-108.

Theiss, M. (2006), Kapitat społeczny środowiska lokalnego - pojęcia i problemy, [Social capital of the local environment - concepts and problems], [in:] W. Theiss, B. Skrzypek (eds.), Edukacja i animacja spoteczna w środowisku lokalnym [Education and social animation in the local environment], (Warszawa: Centrum Wspierania Aktywności Lokalnej CAL): 109-126. 